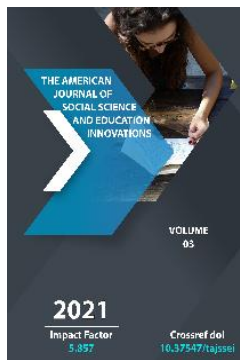

\title{
The Social Essence Of Intelligence
}

\author{
Abdunabi Rustamovich Turaev \\ Independent Researcher, University Of Tourism "Silk Road" Samarkand, Uzbekistan
}

Journal Website:

http://usajournalshub.c

om/index,php/tajssei

Copyright: Original content from this work may be used under the terms of the creative commons attributes 4.0 licence.

\section{ABSTRACT}

In this article, the social essence and manifestation features of intelect have been studied epistemologically. The essence of the concept of "perception" is revealed through the study of Intelectni gnoseological. There was also a comparative analysis of the psyche of animals and the process of perception in humans.

\section{KEYWORDS}

Social intelect, psyche, perception, cognition, psyche of intelect animals, man, activity.

\section{INTRODUCTION}

The consideration of the intellect (mind) from the gnoseological point of view is connected with the concept of "perception". Because intellect is the supreme form of reflection of reality from a materialistic point of view. The perception of the quality of the attribute of the whole matter is the potential of material systems in the process of mutual movement to create the peculiarities of other systems by means of their own peculiarities. The 
soundness of perception arises from the totality of material mutual action. All material objects in the universe constantly interact with each other, leaving behind certain changes in each other. We observe this regularly in everyday life.

Every person has a certain level of intellectual potential. If all the conditions necessary for the full emergence of this internal power are created, then contemplation will get rid of all sorts of hardened old concepts and beliefs. And all the unique abilities and talents that Allah has bestowed upon any person is complete primarily for himself, for the wellbeing, happiness, benefit of his family, nation and people, state fortunately, such a society develops so strongly that it is not easy to even imagine its image and effect. The contribution of every member of our society to the achievement of the Great Goals that stand before us is inevitable from this account to be incomparable [6:74].

\section{MATERIALS AND METHODS}

Intellect manifests itself as the rational potential of a person to acquire knowledge, to re-create, maintain and restore them, to reensure the management of human beings and their valuable goals, to communicate and exchange experience, and to convey it from one generation to another. Intellect unites the possibilities of creativity (the means of existence and free development of an individual izlash, the creation of new knowledge, the creation of works of art, the prediction of the future, the adoption of decisions, etc.), which are carried out throughout the life of a person. Every person has a certain level of intellectual potential. If all the conditions necessary for the full emergence of this internal power are created, then contemplation will get rid of all sorts of hardened old concepts and beliefs. And if any person gives his unique abilities and talents, which Allah has bestowed, first of all, for himself, for the well-being, happiness, benefit of his family, nation and people, of his state, such a society will develop so strongly that it is not easy to even imagine its image and effect. The contribution of every member of our society to the achievement of the Great Goals that stand before us is inevitable from this account to be incomparable [1:74].

Knowledge is a component of the mind, it is about the state or a certain (scientific, cultural, educational, spiritual, military and general.) a set of scientific, practical information, concepts related to the fields.[2:93]

Material conditions for the occurrence of intelect are rooted in in inanimate nature (in the inorganic world )gandir. For this level of matter, the perception belongs to the elemental forms: mechanical, physical, chemical forms. These forms of perception differ in their nonfunctional nofunctional nature. The systems that reflect and reflect here are only conditionally separated. As a result of the interaction of systems (objects), the exchange of substances, energy, chemical composition occurs. Traces of snow can be an example of reflection inanimate nature.

With the advent of life on Earth, there was a qualitative jump in the evolution of perception forms, a biological form of reflection arose. It includes such types of reflection as excitation, perception and psyche. Biological perception this is a functional perception. It emerges as a manager of purposeful activity as well as flexible behavior. Excitation is the reaction of these living organisms to certain conditions of the environment in which vital activity occurs 
in the body. Excitation applies at the level of plants and organisms of single-tissue existence. For example, plant products react to light, temperature, humidity, etc. Sensuality is the reflection of lower beings in the form of perception with the help of members of perception belonging to parts of the external world and certain properties.

Intellect (latin: intellectus - understanding, cognition, reason) is a set of mental abilities of a person and some higher animals, a relatively stable system of mental actions, operations and abilities that determines the cognitive style of the subject and is aimed at forming an adequate scheme of the surrounding world and the image of the - self. [3:281-283]

The socio-practical nature of society also manifests itself in the modern stage of society. The potential for thinking is not inherited by the birth of a person. It is transmitted from generation to generation through forms of culture. In order for a person to have a special thinking potential, he must undergo socialization, that is, he has since childhood entered into the system of social relations and develop in accordance with the requirements and norms of this system. This is evidenced by the "upbringing" of children who lived among these animals. Such children returned to society could not socialize. About the social practical nature of intelect soviet scientists A.I. Metsheryakov, S.l.Sokolyansky and E.V.Popular experiments conducted under the leadership of llenkov on the upbringing of blind, deaf children are also indicative.

It is also necessary to touch on the structure of the content of intelligence in the most general way, taking into account theesnieseseological. In the process of Labor and other activities, including in the process of learning, intelligence is filled with a certain content. Against this background, both the content of intelligence and the object are distinguished (determined) by the subject. In the process of perception, something will depend on the object being reflected and will return from it. In that sense, it is objective. And something goes from the reflecting subject to the perception. In this sense, it is a subspecies. The unity of objectivity and subjectivity is a structural feature of the content of intelligence. The object of the external scientist and its gneseological appearance in intelect are largely consistent in its content. And the content of the object itself is ultimately determined by the object. However, in connection with the complexity of the object universe, the murkiness of the process of perception, and the activity of the subject, intellect often creates a conflict between objectivity and subjectivity. This leads to a state of doubt about the correctness of the reflection of the outside world in intelligence to some state of uncertainty in intellect, inherent in all people. This is a complete natural and legitimate state of affairs. As V.V.Mayakovsky points out, it is not surprising that "A person who always knows everything, in my opinion, is just a stupid person", the need for knowledge verification (content) arises from the fact that the restoration of the universe in intelligence is of an extimol nature. But the conflict between objectivity and subjectivity is also of positive importance. It arises as an internal source of interest, a source of improvement in knowledge and, even more so, a thirst for knowledge, but the main source of the listed phenomena is experience. The contradictory nature of intelect (gnoseological meaning) is regularly manifested in everyday experience. In connection with this, the 
reasoning about the fact that thinking is always self - quarreling seems to be correct.

Thought-the process for the functioning of consciousness. [4.329]

In scientific research, intell in accordance with various aspects of the review, the intellect is divided into structures on different grounds, as well as its various levels, spheres, unsurlari (joints) functions and properties are distinguished. For example, according to the thinking feature (level)of the subject, his psychic activity in relation to reality is divided into two main levels, the above mentioned: intellect (more precisely, if it is said, it is understood, that is, it is conducted from a clear point of view), as well as from an incomprehensible point of view.

\section{RESULTS}

The structure of intelligence is expressed in its functions. Intelect duties of the individual are determined by the role and role of the mind in the life activities of Man and society. Of course, it is somehow conditional to distinguish the exact functions of such a complex integrity in the quality of intelligence. Often, the tasks of intelect are shown as learner, goal-setting, avoidance, communicative-management and creativity (reshaping). With the help of learning tasks, the formation of ideal examples of reality occurs. Knowledge creation is carried out. With the help of the goal setting task, a person develops the goal of his activity. Carries out pre-knowledge in the results of activities. With the help of the sensory function, a person analyzes his thoughts and senses. As a result of this feeling, doubts arise about the correctness of his knowledge and behavior. The task of communicative-management refers to the establishment of relations between people and social groups. During the implementation of this task, certain norms of communication and behavior are formed. It is known that the mind not only reflects the universe ,but also creates it (reshapetiradi). This is the work of fundamental creativity on the formation of intelect second nature - the material and spiritual world.

Out of the mind - it is unclear, pinchony, but are deeply determining factors of a person intelect. For example, instincts, hidden ambitions, dreams, etc.are included in the main sentence. With the problem of non-intelect in the XIX-XX centuries A.Shopengauer, E.Gartman, F. Nisshe and Z.Freyd (on the concept of Z.Freyd, see the topic "Nature and the existence of man") was engaged. The peculiarity of the interpretation given to the mind by the mentioned philosophers is that the role of the outside state in the spiritual and spiritual life of a person is absent. Russian philosopher A.V.Ivanov "mind and thought" (M.,1994) distinguished the following four areas of thinking on a functional activity basis in his work. [5: 170]

Social intelligence is a dialectical connection with social consciousness. Social development is tied to the intellectual potential in society. [6.21] The problem of intelligence has always attracted the serious attention of scientists, because the definition of the specificity of the interaction of man's role and role in the universe with the reality that surrounds him implies the determination of the nature of human intelligence. For philosophy, the essence of this problem intelect is also characterized by the fact that the question of the nature of its attitude to life touches upon the initial worldview and methodological guidelines of any philosophical direction that he or she supports. 
On the basis of the formation of nondirectional, sectorial innovation thinking is aimed at the development, implementation and dissemination of new ideas, after the activity becomes a routine process, creative thinking rises to the level of productive, creative activity, that is, productive activity. In this way, cognitive, intellectual innovation is formed. [7.571]

Of course, these comrades can be extremely diverse. But all of them, in essence, are the only problem, work with the analysis of intelect in the quality of a specific human form of establishing and controlling the interaction of man with reality. This form is most characterized by the fact that avalo distinguishes a person as the owner of specific methods of management, including specific reality, interaction with the surrounding world.

\section{CONCLUSION}

In this regard it is necessary to connect with intellect, of course, self-awareness. The development of complex forms of selfconsciousness occurs only in the later stages of the history of the development of human thought, at a time when self-consciousness reached a certain level of self-independence, but its origin can be understood only on the basis of the consideration of the existence of intelligence in general. Thus, intelligence arises as a fundamental, elementary philosophical concept for the analysis of all forms of manifestation of the spiritual and spiritual life of a person, their analysis in unity and integrity, as well as the establishment of his interaction with the surrounding world, the methods of managing and controlling these interactions.

\section{REFERENCES}

1. Karimov I. Youth is the decisive force of our present and tomorrow's life T.: "Spirituality", 2015. - P.128.

2. Yaxshilikov J., Muhammad N. - Philosophy of technical and information technologies, - Samarkand.: "SamSU" 2019. - P.216.

3. Gurevich P.S. Intellect // Gurevich P.S. Psychologicheskiy slovar. M., 2007. - P. 281-283.

4. Turaev B.A. Ontology, gnoseology, problems of logic and philosophy of science. Selected works: Volume I. Publishing house of UZMK, 2015. - P.376.

5. Ivanov A.V. Consciousness and contemplation. M., 1994. - P.290.

6. Yazdonov.T. The functional importance of social consciousness forms in the organization, management and control of public opinion. // Doctor of philosophy (DSC) dissertation atoreferati. Samarkand2020. - P.36.

7. Sultanova G.S. Innovative thinking and heuristics// ACADEMICIA: An International Multidisciplinary Research Journal https://www.saarj.com 1 ISSN: 2249-7137 Vol. 10, Issue 4, April 2020.-P. 568-574.

8. Juraev, Z. M., \& Masalieva, O. M. (2020). Eleven Ahmad Pilgrimage And Seal And Flag Of Victory. The American Journal of Social Science and Education Innovations, 2(12), 43-50. 